International Business and Global Economy 2019, no. 38, pp. 105-118

Biznes międzynarodowy w gospodarce globalnej 2019, nr 38, s. 105-118

Edited by the Institute of International Business, University of Gdańsk

ISSN 2300-6102

e-ISSN 2353-9496

DOI 10.4467/23539496IB.19.006.11505

Bamituni Etomi Abamu

Wekerle Business School

Joanna Pietrzak

University of Gdańsk

\title{
Relationship between FDI and international trade - evidence from Nigeria
}

Foreign direct investment (FDI) is now an important factor in the development of an economy considering the benefits that come with it. This study aims to investigate the relationship between FDI and international trade from an exports perspective. A correlation analysis was performed to determine whether there is a relationship between the two variables. Findings show that there is a strong positive relationship between FDI and exports. A regression analysis using OLS showed a very significant relationship between the two and revealed that an increase in FDI causes an increase in the country's exports. The composition of exports is limited as oil accounts for more than $90 \%$ of Nigeria's exports, thereby exposing the country to external shocks. This study recommends that more efforts should be made to diversify the economy by attracting FDI to non-oil sectors such as agriculture, manufacturing, and mining in order to diversify the export base.

Keywords: international trade, foreign direct investments, exports

JEL classification: F1, F2, F11, F21, F23

\section{Zależność między inwestycjami bezpośrednimi a handlem międzynarodowym - perspektywa Nigerii}

Bezpośrednie inwestycje zagraniczne (BIZ) są znaczącym czynnikiem rozwoju ekonomicznego. Niniejszy artykuł ma na celu zbadanie zależności między napływem BIZ a poziomem eksportu w kraju przyjmującym na przykładzie Nigerii. Zależność między tymi dwoma zmiennymi została zbadana metodą korelacji. Wyniki wskazują na istnienie silnego związku między BIZ a eksportem. Analiza regresji z użyciem OLS wskazuje, że wzrost zagranicznych inwestycji bezpośrednich powoduje wzrost wartości eksportu. Struktura eksportu Nigerii jest uproszczona, jako że ropa naftowa stanowi $90 \%$ jego wartości, co naraża kraj na szoki zewnętrzne. Autorzy zalecają, aby rząd położył większy nacisk na przyciąganie inwestycji zagranicznych do innych sektorów, takich jak rolnictwo, przemysł wytwórczy i wydobywczy, aby zdywersyfikować strukturę eksportu Nigerii.

Słowa kluczowe: handel międzynarodowy, bezpośrednie inwestycje zagraniczne, eksport

Klasyfikacja JEL: F1, F2, F11, F21, F23 


\section{Introduction}

As global economies become integrated and increasingly liberalized, two variables that have played a huge role in international economic relations and the globalization process are foreign direct investment and international trade. International trade is basically the exchange of goods and services across international borders [Rugman, Collinson, Hodgets, 2006], and FDI has been defined as 'the flow of funding provided by an investor or a lender (usually a firm) to establish or acquire a foreign company or to expand or finance an existing foreign company that the investor owns and controls' [Pugel, 2009]. These two variables have become increasingly interrelated in today's global economy with the emergence of multinational firms. Studies have shown, however, that this relationship varies from one country to another. This paper focuses on the relationship between FDI and international trade within the context of Nigerian exports.

\section{Theoretical background}

\subsection{International trade theories}

International trade theories analyse and provide explanations for the pattern of international trade, its origins, as well as the distribution of the benefits from trade. The first international trade theories under organized economics can be traced back to classical economists [Ricardo, 1817; Smith, 1776] who introduced the theories of absolute advantage and comparative advantage. The first main theory of international trade within organized economics was developed by Adam Smith in his book An inquiry into the nature and causes of the wealth of nations published in 1776 . While criticizing the idea of mercantilism which advocates the use of state regulation to create wealth and growth, Smith promotes the policy of free trade and discusses the gains thereof. To further explain this idea, the theory of absolute advantage was developed. The absolute advantage theory suggests that nations should specialize in the production of the goods they can produce more cheaply than others. A country will refuse to trade if it lost or gained nothing and a trade which is mutually beneficial takes place hinged on absolute advantage. The basis for the absolute advantage theory is the division of labour, which increases the productive power of labour. On the other hand, David Ricardo's theory of comparative advantage argues that it is the comparative differences that determine the trade relations between two nations. This theory was developed to provide an explanation as to why nations will engage in international trade despite the ability of one country's workers to produce every single good more efficiently 
at an absolute advantage than the workers in the other countries. The law of comparative advantage explains that each country will specialize in the production of those products in which they have the highest comparative advantage or the lowest comparative disadvantage. Ricardo [1817] identifies technology as an important variable that explains international trade patterns. Emphasis is on the differences in production technologies that influence a nation to engage in specialization and production of goods in which it possesses a comparative advantage. The differences in technology between nations are also major sources of the movement of goods beyond geographical boundaries. Ricardo's theory was further built on by Eli Heckscher and Bertil Ohlin who developed the factor endowment theory based on an observation that the nations' endowment with different factors, such as natural resources, is the basis for international trade.

\subsection{Foreign direct investment theories}

Theories of foreign direct investments were borne out of the traditions of international trade. Heckscher and Ohlin suggested that FDI or the location of production were determined by differences in factor endowments, while Ricardo's model argued that the location of production was determined by the difference in labour productivity. Stephen Hymer [1976] was one of the pioneers in establishing a systematic approach towards the study of FDI. His work on FDI has been corroborated and further developed by other studies [Kindleberger, 1969; Knickerbocker, 1973; Caves, 1974; Dunning, 1974; Cohen, 1975]. Through his industrial organization theory, Hymer argues that multinational firms exist due to market imperfections which are structural in nature and caused a divergence from perfect competition in the market of the final product. Peter Buckley and Mark Casson [1976] developed the internalization theory to describe the growth of multinational firms. The theory suggests that through the internalization of economic activities, the firm can overcome market imperfections like tariff and non-tariff barriers. According to Buckley and Casson, the firm will indulge in internalization when there is an imperfection in the external market or when the cost of producing through external sources is high. Raymond Vernon [1966], through his international production cycle theory, argues that FDI takes place due to the threat a firm faces in a market that it usually exports to and also due to the need to access cheaper factors in those countries where it faces competition.

John Dunning's eclectic paradigm [1976] is regarded as one of the most comprehensive and inclusive theories of FDI. Also referred to as the OLI paradigm, the theory suggests that a firm will engage in FDI if it possesses an ownership advantage, a location advantage, and an internalization advantage. Under this OLI framework, Dunning acknowledges and combines the firm's microeconomic 
characteristics as well as the macroeconomic characteristics of the country that attracts FDI by focusing on the trade-offs between the firm investing abroad against exporting from its home country base. The microeconomic factors focus on the firm's internal constraints and opportunities while the macroeconomic factors focus on the conditions of the host country that make it an attractive location for foreign investment [Gerber, 2014]. Ownership advantages are those unique advantages specific to foreign firms that enable them to compete with other firms in the local market. Locational advantages are advantages specific to the target market (e.g. natural resources) which are available for firms to exploit when they move production. Internalization advantages are those capabilities that enable the firm to internalize or control its own business activities rather outsource them.

\section{Literature review}

The literature on the relationship between FDI and international trade is focused on two outcomes: substitution or complementary. While some studies show a substitution relationship between FDI and trade [Mundell, 1957; Blonigen, 1997; Brainard, 1993], other studies have revealed a relationship that is complementary [Schmitz, Helmberger, 1970; Kojima, 1975]. Based on the theory of the multinational firm, it is well established that FDI tends to substitute for trade as the firm decides to internationalise through horizontal FDI instead of the export alternative [Markusen, 1984; Markusen, Venables, 1998; Türkcan, 2006]. On the other hand, FDI complements trade when focusing on the vertical FDI linkages [Helpman, 1984; Clausing, 2000]. Other studies argue that the substitution or complementary relationship between FDI and trade depends on the possession of some or all advantages in the OLI framework [Chiappini, 2016].

\subsection{FDI and trade as substitutes}

The general explanation of a substitution relationship between FDI and trade is that an increase in FDI will decrease exports to foreign countries and vice versa. Also, when a multinational firm decides to invest directly in a host country's economy instead of exporting like it used to, a substitution of trade for FDI takes place. Robert Mundell [1957] first studied the substitution relationship between FDI and international trade using the general Heckscher-Ohlin model to demonstrate that capital movements are influenced by trade barriers. Mundell further adds that import tariffs decrease exports and influence FDI flows. Lael Brainard [1993] makes a case for a substitution relationship linking it to a proximity-concentration tradeoff approach. This suggests that FDI will be considered as an alternative to export 
when the fixed costs of setting up a new subsidiary are lower than trade costs. With higher transportation costs and trade barriers, firms will likely choose FDI over exports especially with lower barriers for investments and the size of scale economies at the plant level in relation to the corporate level [Brainard, 1993]. James Markusen [1995] also shares the same view of the horizontal multinational seen as an alternative option to trade when the cost of transportation and rates increase even as FDI grows at a greater proportion than trade.

FDI is seen as a substitute of trade if the FDI is horizontal in nature. Horizontal FDI takes place for the purpose of supplying a market with goods and services. This can be viewed as a market-seeking FDI as identified by Dunning [1980]. Rather than export to the target market, the firm instead decides to establish a production facility in the host country that is similar to that of the home country. This is replicated in every other country the firm operates in and the purpose is to service the local market directly. In this case, FDI is substituted for exports therefore avoiding transportation costs and other trade barriers such as tariffs [Markusen, Venables, 2000]. Substitution effects could arise from an import substitution policy whose aim is the replacement of certain imported goods with the production of the same goods in the country. Firms who export to these country markets are forced to set up production facilities there and thus replace their exporting activities with FDI. Such FDIs are mostly market-seeking and according to Dominick Salvatore [2012], the market for these products already exists. Therefore, to the advantage of the firm, the risks involved in setting up a production facility are low or minimized.

Dunning's [1977] eclectic paradigm supports a substitution relationship between FDI and trade as it has been established that if a multinational firm possesses all advantages (ownership, location, and internalization), it tends to choose FDI over exports. According to Raphaël Chiappini [2016], the firm will choose the export option if it possesses only ownership and internalization advantages. Therefore the choice of FDI or exports depends on these three advantages and as earlier stated, the firm will decide to invest abroad through FDI if it benefits from the OLI advantages, thus confirming a substitution relationship between FDI and trade.

\subsection{FDI and trade as complements}

The general assumption for the complementarity between FDI and trade is that both FDI and exports should move in the same direction. This means that when FDI increases, exports also increases and vice versa. The complementarity between FDI and trade is increasing due to the rise in the fragmentation of production, in combination with established distribution networks covering many 
continents. According to Kiyoshi Kojima [1975], FDI and international trade are complementary if FDI creates or expands the opportunity to export. Based on a sectoral investigation, Kiyoshi Kojima [1982] and Terutomo Ozawa [1991] conclude that FDI will likely occur in those sectors in which the home country lacks a comparative advantage. According to Robert Lipsey and Merle Yahr Weiss [1981], FDI and exports are complements when the production of one product by foreign subsidiaries increases the demand for the whole product line. A case for a complementary relationship was made by Andrew Schmitz and Peter Helmberger [1970] in their examination of the extractive industry. Based on the assumption that one country with a large domestic market demand for a specific natural resource is also a capital surplus country while the other country with an abundance of that natural resource has inadequate capital and the required technology to extract it, they argue that the country with surplus capital makes FDI in the country with the abundant resource. This creates new trade in the form of exportation of the extracted resource from the latter to the former [Schmitz, Helmberger, 1970]. Li-Gang Liu and Edward Graham [1998] also argue that FDI creates new markets for a host country. The presence of FDI develops marketing and distribution capabilities that might enable the exportation of goods and services to foreign markets that would not be possible without FDI. This makes FDI and trade complements.

A complementary relationship can be observed in the case of vertical FDI. The aim of vertical FDI is to achieve economies of scale, where the location of production is based on cost minimization. Vertical FDI is undertaken by firms in order to move the stages of production such as assembling and intermediate, which are labour intensive, to countries with cheaper labour. José Pedro Pontes [2004] and Ana Paula Africano and Manuela Magalhaes [2005] reveal that FDI and trade are complements when foreign investments are vertical, based on the theory of a firm's location. According to Paul Krugman, Marc Melitz, and Maurice Obstfeld [2012], vertical FDI is mainly driven by the differences in production costs between countries in contrast to transport costs and trade barriers which influence horizontal FDI. Elhanan Helpman [1984] further adds that each segment of the production process is located in countries which possess the required factor in abundance. Hence vertical FDIs are also considered efficiency-seeking FDIs. A complementary relationship between FDI and export is identified as the intermediate goods that are produced in one country are shipped to their affiliates in other countries for further processing. 


\section{Nigerian economy}

\subsection{Analysis of Nigeria's exports}

Before the discovery of oil, Nigeria's economy was agro-based and this was also reflected in the country's exports. As the main economic activity, agriculture accounted for $70 \%$ of foreign revenue [Daramola et al., 2008]. There was food sufficiency in the country and a surplus for exports. The country exported agricultural commodities such as groundnuts, oil palm and palm kernel, cocoa, coffee, hide and skin, and rubber. After oil was discovered in 1956, the country began to shift its focus towards it [Ifeanyi et al., 2008] and there was a high influx of foreign exchange. As a result, other sectors were neglected. With the oil boom in the 1970s, more foreign revenues came into the country. However, a fall in oil prices revealed the danger in the overreliance on oil exports for revenue. Real interest rates and inflation began to rise as foreign exchange began to dry up. Despite the intention to diversify the economy, there was no will to implement economic policies. The country still depends on oil exports and the volatility in the global oil markets continues to affect the country's economy. Today, Nigeria is regarded as an oil economy with oil accounting for more than $90 \%$ of its exports.

\subsection{Analysis of Nigeria's inward FDI}

Nigeria is an important destination for FDI in Africa because of its large population and abundance of natural resources. The country has the highest population in Africa with over 190 million people and is also the largest producer of oil with largest proven gas reserves on the continent. This makes it attractive for market-seeking and natural resource-seeking investments. The basis for FDI in Nigeria, a former British colony, was formed from the perspective of imperial expansion as state trading companies created subsidiaries in the country [Olise et al., 2013]. Nigeria was a host to foreign companies such as United Africa Company (UAC) and Leventis, which were involved in the purchase and export of cash crops. With the first oil discovery, investments flowed into the country mainly from oil companies such as Mobil, Agip, Gulf (now Chevron), Tenneco (later Texaco) and Safrap (later Elf), Philips Great Basins Texaco Overseas and Union [Fregene, 1998]. In recent times, FDI inflows have been falling as a result of several factors. The commodity price bust has negatively affected FDI. However, FDI flows into the country are becoming diversified as the country has been able to attract market-seeking technology FDIs from US firms such as Facebook, Uber, and Emergent Payments. Efficiency-seeking FDIs into the manufacturing sub-sectors like textile, aerospace, and automotive have been attracted from Chinese firms. 
However, the only FDIs that may encourage exports are efficiency-seeking and not market-seeking ones.

\section{Relationship between Nigerian FDI inflow and exports - econometric methodology}

\subsection{Model specification and data sources}

An increase in exports will depend on the motives of the investor and, as discussed in the literature, if FDI seeks to benefit from a comparative advantage perspective through exploitation of natural resources and labour, a positive relationship between FDI and trade is expected. On the other hand, the relationship will be negative if the motive behind FDI is to avoid export barriers and exploit the country's market. Also, the increase in factor supply which is represented by capital will also increase the supply capacity in terms of productivity.

The study has selected a bivariate model to examine the relationship between export and FDI:

$$
\mathrm{EXP}=\mathrm{f}(\mathrm{FDI})
$$

This is shown in explicit econometrics form in a simple linear regression model as:

$$
\mathrm{EXP}=\beta 0+\beta 1 \cdot \mathrm{FDI}+u
$$

where:

EXP - total country exports,

FDI - net FDI inflows,

$\beta 0$ - intercept or constant amount,

$\beta 1-$ coefficient of the explanatory variable,

u - error term.

Two methods have been applied to verify the model: descriptive statistics and correlation analysis. Descriptive statistics is used to describe the main features of data collection through the use of numerical and graphical methods. This study will present the descriptive conditions of both FDI and exports by using the mean, maximum, minimum, and standard deviation values.

The main aim of a correlation analysis is to see if there is a co-variation between two measurement variables, and also to quantify the relationship strength between the variables. Correlation analysis will test and measure the strength of the relationship between the FDI (explanatory variable) and export (dependent variable). 
Table 1. FDI and exports in the years 1995-2017, in USD

\begin{tabular}{|c|c|c|}
\hline Year & Net FDI inflow & Exports \\
\hline 1995 & $1,079,271,551.04$ & $3,840,512,881.58$ \\
\hline 1996 & $1,593,459,221.79$ & $5,279,477,112.82$ \\
\hline 1997 & $1,539,445,718.15$ & $4,878,570,066.57$ \\
\hline 1998 & $1,051,326,216.95$ & $2,808,064,126.79$ \\
\hline 1999 & $1,004,916,719.01$ & $13,855,883,974.22$ \\
\hline 2000 & $1,140,167,556.02$ & $20,965,436,458.51$ \\
\hline 2001 & $1,190,618,643.59$ & $19,644,892,959.49$ \\
\hline 2002 & $1,874,070,753.14$ & $18,137,444,461.16$ \\
\hline 2003 & $2,005,353,563.06$ & $27,448,726,478.04$ \\
\hline 2004 & $1,874,060,886.98$ & $38,102,757,791.76$ \\
\hline 2005 & $4,982,533,930.22$ & $56,994,046,166.68$ \\
\hline 2006 & $4,854,353,979.09$ & $59,232,839,787.02$ \\
\hline 2007 & $6,036,021,404.82$ & $67,494,191,530.98$ \\
\hline 2008 & $8,195,499,253.29$ & $88,023,848,293.47$ \\
\hline 2009 & $8,554,740,716.54$ & $58,384,595,091.09$ \\
\hline 2010 & $6,026,232,041.28$ & $82,698,980,431.78$ \\
\hline 2011 & $8,841,113,286.95$ & $102,438,079,434.95$ \\
\hline 2012 & $7,069,934,204.80$ & $98,524,143,135.90$ \\
\hline 2013 & $5,562,873,605.74$ & $99,419,264,724.26$ \\
\hline 2014 & $4,651,465,947.82$ & $83,829,813,832.50$ \\
\hline 2015 & $3,137,318,699.78$ & $50,377,538,493.88$ \\
\hline 2016 & $4,445,102,771.13$ & $38,413,256,103.69$ \\
\hline 2017 & $3,497,233,434.78$ & $50,764,155,610.62$ \\
\hline
\end{tabular}

Source: International Monetary Fund database.

\section{Results and analysis}

Table 2. Summary statistics

\begin{tabular}{|l|r|r|}
\hline & \multicolumn{1}{|c|}{ Net FDI inflow } & \multicolumn{1}{c|}{ Exports } \\
\hline Mean & $3,922,048,439.39$ & $47,458,979,084.68$ \\
\hline Maximum & $8,841,113,286.95$ & $102,438,079,434.95$ \\
\hline Minimum & $1,004,916,719.01$ & $2,808,064,126.79$ \\
\hline Median & $3,497,233,434.78$ & $50,377,538,493.88$ \\
\hline Standard deviation & 2630313416 & 33597140140 \\
\hline
\end{tabular}

The descriptive statistics of the study variables is shown in Table 1. As shown in the table, the arithmetic mean representing the average FDI inflow within the 
study period was USD 3,922,048,439.39. The highest inflow of FDI experienced was USD 8,841,113,286.95 in 2011, while the lowest inflow occurred in 1999 with a value of USD 1,004,916,719.01.

For exports, the arithmetic mean value was USD 47,458,979,084.68. Exports was highest in 2011 with a total of USD 102,438,079,434.95 and was at a minimum in 1998 with a total of USD 2,808,064,126.79.

\subsection{Correlation results}

Table 3. FDI and exports, correlation matrix

\begin{tabular}{|l|c|r|}
\hline Net FDI inflow & Exports & \\
\hline 1.0000 & 0.8812 & Net FDI inflow \\
\hline & 1.0000 & Exports \\
\hline
\end{tabular}

Note: Correlation coefficients, using the observations from the years 1995-2017, 5\%; critical value (two-tailed) $=0.4132$ for $\mathrm{n}=23$.

Source: Own elaboration.

The results in the correlation matrix above show that the correlation coefficient between FDI and export is $\mathrm{r}(21)=0.88121659$. This shows a strong positive relationship between both variables. The graph below shows that FDI and exports move in the same direction and closely related in trend signifying a strong impact of FDI on Nigerian exports.

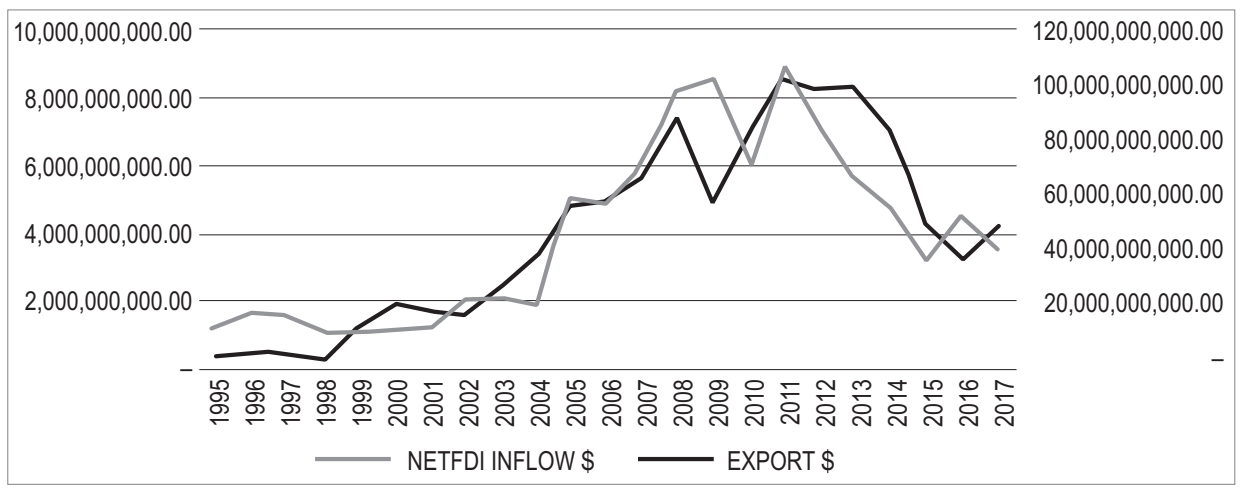

Figure 1. Time series trend of FDI and exports in Nigeria in the years 1985-2017 Source: Own elaboration based on UNCTAD data. 


\subsection{Simple regression results}

Table 4. FDI and exports, simple regression

\begin{tabular}{|l|c|c|c|c|c|}
\hline & Coefficient & Std. Error & t-ratio & p-value & \\
\hline const & -3.23817 & 3.61261 & -0.8964 & 0.3802 & \\
\hline 1_NETFDIINFLOW & 1.25497 & 0.165347 & 7.590 & .0001 & $* * *$ \\
\hline
\end{tabular}

\begin{tabular}{|l|c|l|l|}
\hline Mean dependent var & 24.16526 & S.D. dependent var & 1.118452 \\
\hline Sum squared resid & 7.352176 & S.E. of regression & 0.591696 \\
\hline R-squared & 0.732848 & Adjusted R-squared & 0.720126 \\
\hline $\mathrm{F}(1,21)$ & 57.60689 & P-value(F) & $1.89 \mathrm{e}-07$ \\
\hline Log-likelihood & -19.51986 & Akaike criterion & 43.03972 \\
\hline Schwarz criterion & 45.31071 & Hannan-Quinn & 43.61087 \\
\hline rho & 0.537807 & Durbin-Watson & 0.839251 \\
\hline
\end{tabular}

Note: Model 3: OLS, using observations from the years 1995-2017 $(\mathrm{T}=23)$, dependent variable: 1_EXPORTS. Source: Own elaboration.

Using a simple linear regression model, the coefficient for net FDI inflow is 1.25497 and was significant with a $p$ value of .0001 . This means that for every unit increase in FDI, exports will increase by 1.25497 .

The findings as shown above indicate that FDI is a key determinant of exports in Nigeria. Both variables are strongly related and move in the same direction and explain the changes in exports. This finding supports the findings of Obiora Gideon Okechukwu, Glauco De Vita, and Yun Luo [2018] who found a positive and significant relationship between FDI and exports in Nigeria. Alexander Abraham Anfofum, Joshua Samuel Gambo, and Tauhid Suleiman [2013], while studying the impact of FDI on the economy, found that FDI has a positive impact on exports.

\section{Conclusions}

The aim of this study was to examine the relationship between FDI inflows into Nigeria and the country's exports. The study achieved this objective using a correlation and simple regression analysis to test the strength of and estimate the relationship between the two variables. It established that there is a strong, statistically significant relationship between FDI and exports. In summary, this reveals that FDI and exports are positively interrelated and the relationship is complementary. However, with FDI and export values seemingly affected by global oil 
prices, it is recommended that the government and policy makers engage in FDI diversification in order to reduce the exposure of the country's economy to external shocks and expand the export base.

\section{References}

Africano AP., Magalhaes M., 2005, FDI and Trade in Portugal: A gravity analysis, Universidade do Porto, FEP Working Paper, no. 174.

Anfofum A.A., Gambo J.S., Suleiman T., 2013, Estimating the impact of foreign direct investment in Nigeria, International Journal of Humanities and Social Science, no. 17.

Blomstrom M., Kokko A., Golberman S., 1998, Regional economic integration and FDI: The North American experience, Economic Research Institute, Stockholm School of Economics, Stockholm, Sweden., Working Paper Series in Economics and Finance, no. 269.

Blonigen B.A., 1997, Firm-specific assets and the link between exchange rates and foreign direct investment, American Economic Review, no. 3.

Brainard S.L., 1993, An empirical assessment of the factor proportions explanation of multinational sales, NBER Working paper no. 4583.

Buckley P., Casson P., 1976, The future of the multinational enterprise, MacMillan, London. Caves R.E., 1974, Economic analysis and multinational enterprise, Allen \& Unwin, London.

Chiappini R., 2016, Do overseas investments create or replace trade? New insights from a macrosectoral study on Japan, The Journal of International Trade \& Economic Development, no. 3.

Clausing K.A., 2000, Does multinational activity displace trade, Economic Inquiry, no. 2.

Cohen B., 1975, Multinational firms and Asian exports, Yale University Press, London.

Daramola A., Ehui S., Ukeje E., McIntire J., 2008, Agricultural export potential in Nigeria, [in:] Economic policy options for a prosperous Nigeria, eds. P. Collier, C.C. Soludo, C.A. Pattillo, Palgrave Macmillan, New York, NY.

Dunning J.H., 1974, The distinctive nature of the multinational enterprise, [in:] Economic analysis and the multinational enterprise, ed. J.H. Dunning, Allen \& Unwin, London.

Dunning J.H., 1977, Trade, location of economic activity and the multinational enterprise: A search for an eclectic approach, [in:] The international allocation of economic activity: Proceedings of a Nobel symposium; Stockholm, 8-11 June, 1976, eds. B. Ohlin, P.-O. Hesselborn, P.M. Wijkman, Macmillan, London.

Dunning J.H., 1980, Toward an eclectic theory of international production: Some empirical tests, Journal of International Business Studies, no. 1.

Fregene P., 1998, Oil exploration and production activities: The socio-economic and environmental problems in Warri division - Itsekiri homeland, [in:] Oil exploration and exploitation: The state and crises in Nigeria's oil bearing enclave, ed. F. Adewumi, Friedrich Ebert Foundation, Lagos.

Gerber J., 2014, International economics, Pearson, Harlow.

Helpman E., 1984, A simple theory of international trade with multinational corporations, The Journal of Political Economy, no. 3.

Hymer S.H., 1976, The international operations of national firms: A study of direct foreign investment, MIT Press, Cambridge, MA.

Ifeanyi N.N., Felix C., Remy O.M., Jude C.N., Nnanna M.A.M., Joe O., 2008, Empirical assessment of Nigeria's agricultural export and economic welfare, MPRA Paper no. 12. 
Kindleberger C.P., 1969, American business abroad, Yale University Press, New Haven, CT.

Knickerbocker F.T., 1973, Oligopolistic reaction and multinational enterprise, Division of Research, Harvard University, Cambridge, MA.

Kojima K., 1975, International trade and foreign direct investment: Substitutes or complements, Hitotsubashi Journal of Economics, no. 16.

Kojima K., 1982, Macroeconomic versus international business approach to direct foreign investment, Hitotsubashi Journal of Economics, no 1.

Krugman P., Melitz M., Obstfeld M., 2012, International economics: Theory and policy, Pearson, Boston.

Lipsey R.E., Weiss M.Y., 1981, Foreign production and exports in manufacturing industries, Review of Economics and Statistics, no. 63.

Liu L.-G., Graham E.M., 1998, The relationship between trade and foreign investment: Empirical results for Taiwan and South Korea, Working Paper Series WP98-7, Peterson Institute for International Economics.

Markusen J.R., 1984, Multinational, multi-plant economies and the gains from trade, Journal of International Economics, no. 16.

Markusen J.R., 1995, The boundaries of multinational enterprises and the theory of international trade, Journal of Economic Perspectives, no. 2.

Markusen J.R., Venables A.J., 1998, Multinational firms and the new trade theory, Journal of International Economics, no. 2.

Markusen J.R., Venables A.J., 2000, The theory of endowment, intra-industry and multi-national trade, Journal of International Economics, no. 2.

Mundell R.A., 1957, International trade and factor mobility, The American Economic Review, no. 3.

Okechukwu O.G., De Vita G., Luo Y., 2018, The impact of FDI on Nigeria's export performance: A sectoral analysis, Journal of Economic Studies, no. 5.

Ohlin B., 1933, Interregional and international trade, Harvard University Press, Cambridge, MA.

Pearce I., Rowen D.C., 1966, A framework for research into the real effects of international capital movements, [in:] Essays in honour of Marco Fanno, ed. T. Bagiott, 2 vols., Cedam, Padova.

Olise M.C., Anigbogu A.T., Okoli M.I., Anyanwu K.N., 2013, Domestic investment and foreign direct investment flows in Nigeria, IOSR Journal of Humanities and Social Science, no. 6.

Ozawa T., 1991, Japanese multinationals and 1992, [in:] Multinationals and Europe 1992, eds. B. Burgenmeier, J.L. Mucchielli, Routledge, London.

Pontes J.P., 2004, A theory of the relationship between foreign direct investment and trade, Economics Bulletin, no. 6 .

Pugel T.A., 2009, International economics, McGraw-Hill, New York, NY.

Ricardo D., 1817, On the principles of political economy and taxation, John Murray, London.

Rugman A., Collinson S., Hodgetts R., 2006, International business, FT Prentice Hall, Harlow.

Salvatore D., 2012, Introduction to international economics, Wiley, Hoboken, NJ.

Smith A., 1776, An inquiry into the nature and causes of the wealth of nations, W. Strahan, T. Cadell, London.

Schmitz A., Helmberger P., 1970, Factor mobility and international trade: The case of complementarity, The American Economic Review, no. 4.

Turkan K., 2006, Foreign direct investment and intermediate goods exports: Evidence from USA, Paper presented on the ETSG 2006. 
Vernon R., 1966, International investment and international trade in the product cycle, Quarterly Journal of Economics, no. 80.

B.E. Abamu ( ) bamituniabamu@gmail.com

Wekerle Business School, Jasmin u. 10, 1083 Budapest, Hungary

J. Pietrzak (®) joanna.pietrzak@ug.edu.pl

Uniwersytet Gdański, Wydział Ekonomiczny, ul. Armii Krajowej 119/121,

81-824 Sopot, Polska 